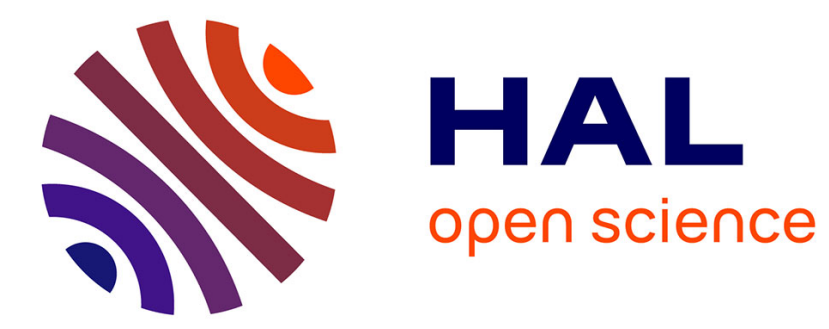

\title{
Nanometric Si/C/N Powders: EXAFS Study at the Silicon K Edge
}

F. Ténégal, A. Flank

\section{To cite this version:}

F. Ténégal, A. Flank. Nanometric Si/C/N Powders : EXAFS Study at the Silicon K Edge. Journal de Physique IV Proceedings, 1997, 7 (C2), pp.C2-1017-C2-1018. 10.1051/jp4:19972123 . jpa-00255182

\section{HAL Id: jpa-00255182 https://hal.science/jpa-00255182}

Submitted on 1 Jan 1997

HAL is a multi-disciplinary open access archive for the deposit and dissemination of scientific research documents, whether they are published or not. The documents may come from teaching and research institutions in France or abroad, or from public or private research centers.
L'archive ouverte pluridisciplinaire HAL, est destinée au dépôt et à la diffusion de documents scientifiques de niveau recherche, publiés ou non, émanant des établissements d'enseignement et de recherche français ou étrangers, des laboratoires publics ou privés. 


\title{
Nanometric Si/C/N Powders: EXAFS Study at the Silicon K Edge
}

\author{
F. Ténégal and A.M. Flank \\ LURE, Centre Universitaire, Bât. 209D, 91405 Orsay, France
}

\begin{abstract}
Preceramic nanosized $\mathrm{Si} / \mathrm{C} / \mathrm{N}$ powders with a variable $\mathrm{C} / \mathrm{N}$ ratio have been investigated by $\mathrm{X}$-ray absorption spectroscopy at the silicon K edge. By combining XANES and EXAFS analysis results, we have proposed a model for the local structure of the as-prepared powders. This structural amorphous model has been tested through multiple scattering calculations using the FEFF code calculations. The evolution during the pyrolysis process is followed, specially for intermediate $\mathrm{C} / \mathrm{N}$ values for which a delay in the crystallisation temperature occurs. Before the formation of very small crystallites, one can observe a reorganisation of the shoit range atomic structure.
\end{abstract}

\section{INTRODUCTION}

The growing interest in ceramics with nanophase structure is explained by their anticipated improved thermomechanical properties and example of superplastic nanocomposite ceramics has already been evidenced. Nanosized Si/C/N powders are attractive as starting materials to produce $\mathrm{SiC}$-and/or $\mathrm{Si}_{3} \mathrm{~N}_{4}$ fine grained ceramics. Such preceramic powders can be obtained by combining the ultrasonic injection of a liquid precursor with the emission of an industrial high power $\mathrm{CO}_{2}$ laser. The liquid precursor is hexamethyldisilazane (HMDS). The chemical composition (i.e. the $\mathrm{C} / \mathrm{N}$ ratio) is controlled under the choice of experimental conditions. The physical properties of these nanometric powders are strongly correlated to their atomic structure. We have investigated $\mathrm{Si} / \mathrm{C} / \mathrm{N}$ powders with a $\mathrm{C} / \mathrm{N}$ ratio variable from 0.3 to 1.3 by $\mathrm{X}$-ray absorption spectroscopy at the silicon $\mathrm{K}$ edge for the as-prepared components (AP), and followed their evolution which is strongly $\mathrm{C} / \mathrm{N}$ ratio dependent. during the pyrolysis process at temperatures ranging from 1000 to $1600^{\circ} \mathrm{C}$. For the low $\mathrm{C} / \mathrm{N}$ value, the crystallisation occurs in a mixture of two phases at temperature as low as $1500^{\circ} \mathrm{C}$, and for high $\mathrm{C} / \mathrm{N}$ value, one can observe an early formation of $\beta$ $\mathrm{SiC}$. But for intermediate $\mathrm{C} / \mathrm{N}$ values, a delay in the crystallisation occurs, and we have focused our study to understand the structural reorganisation which takes place just before the crystallisation.

\section{EXPERIMENTAL AND EXAFS DATA ANALYSIS}

The experimental apparatus for laser synthesis of nanosized powders has already been described elsewhere [1]. The ultrafine $\mathrm{Si}_{\mathrm{x}} \mathrm{C}_{\mathbf{y}} \mathrm{N}_{\mathrm{z}}$ powders were prepared and characterized by quantitative chemical analysis for their composition by $\mathrm{M}$. Cauchetier et al at the CEA(Saclay), and their amorphous state was checked by X-ray and neutron diffusion. The photoabsorption measurements were carried out at LURE, on the SA32 beamline equipped with a double-crystal (InSb (111)) monochromator with an energy resolution of $0.7 \mathrm{eV}$. The incident beam was monitored by measuring the total electron drain current of an aluminum foil located downstream the monochromator. The EXAFS spectra were collected at room temperature, in the transmission mode. All experimental data were recorded relatively to the c-Si energy edge (1839eV at the inflexion point). For the XANES part of the absorption spectra (1830-1910eV), a constant background has been substracted in the preedge region, the spectra were then normalised far from the edge (at $1910 \mathrm{eV}$ ). The extraction of the EXAFS oscillations was performed in a classical way: modelisation of the atomic background by a 4th order polynom, and normalisation using the Heitler approximation. Fourier transforming in $\mathbf{R}$ space of the $\mathbf{k}^{2}$ weighted oscillations was calculated over the same energy range $\left(2.7-10 \AA^{-1}\right)$ for all the compounds and the references. We first used a classical fitting procedure to extract the parameters of the first coordination shell of silicon atoms. Then the fitting procedure was applied to reproduce in a first approximation the structure beyond the first peak. Experimental parameters extracted from model compounds as $\beta-\mathrm{SiC}$ and $\alpha$ and $\beta-S_{3} N_{4}$ were used for the fit of the first and second shell. Finally, starting from these preliminary results, a model was built using the Cerius 3D-sketcher. The coordinates of the atoms in the model were then extracted and used as input to the FEFF code in order to compare the corresponding calculated EXAFS signal, and the experimental one.

\section{RESULTS AND DISCUSSION}

\subsection{Short range order as a function of the $\mathrm{C} / \mathrm{N}$ ratio.}

In a previous paper [2], by combining a study of the XANES, and a modellization of the EXAFS at the silicon K edge, we were able to draw some conclusions about the structural order of the $\mathrm{Si} / \mathrm{C} / \mathrm{N}$ compounds as a function of the $\mathrm{C} / \mathrm{N}$ ratio. 
From the analysis of the first FT peak, we deduced that silicon atoms are surrounded by both $\mathrm{C}$ and $\mathrm{N}$ atoms, with the ratio of the partial coordination numbers NSi-C/NSi-N following the $\mathrm{C} / \mathrm{N}$ atomic ratio and with distances independent on the powder composition, and similar to the one found in respective references. The hypothesis of a random stacking of mixed $\mathrm{SiC}_{\mathrm{X}} \mathrm{N}_{4-\mathrm{x}}$ tetraedra was strengthened by looking at the near edge structure. Figure 1 presents the Si-K XANES spectra for different values of the $\mathrm{C} / \mathrm{N}$ ratio and for two references. As pointed out previously, the threshold position is strongly dependent upon the nature of the atoms which built the tetrahedral environment of $\mathrm{Si}$. Concerning the $\mathrm{Si} / \mathrm{C} / \mathrm{N}$ compounds, the energy position of the absorption threshold varies continuously with the $\mathrm{C} / \mathrm{N}$ ratio, staying at intermediate position between that of SiC and $\mathrm{Si}_{3} \mathrm{~N}_{4}$. A mixture of $\mathrm{SiC}_{4}$ and $\mathrm{SiN} 4$ tetrahedra should present a silicon threshold appearing as a linear combination of the threshold corresponding to both situations, as observed for example when silicon is present with two states of oxydation [3], and as it is the case when the crystallisation has occured (Figure 2).

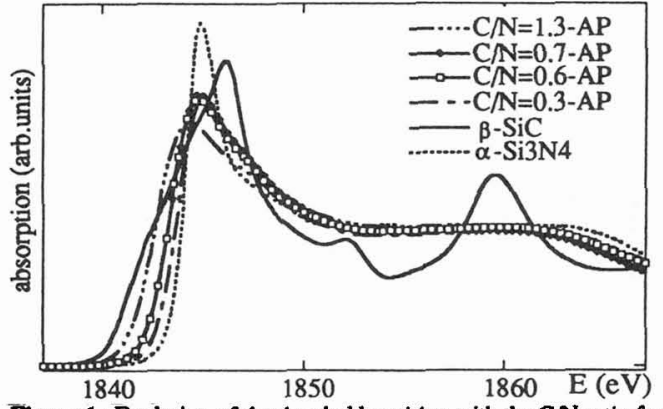

Figure 1 : Evolution of the threshold position with the $\mathrm{C} / \mathrm{N}$ ratio for the as-prepared samples.

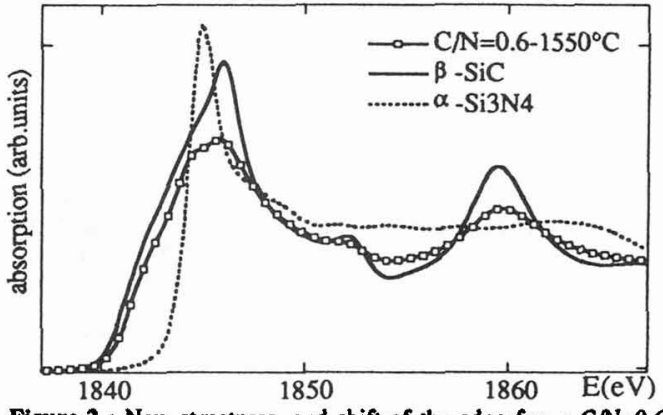

Figure 2 : New structures, and shift of the edge for a $\mathrm{C} / \mathrm{N}=0.6$ sample, at the beginning of the crystallisation.

In a second step, an attempt to simulate the following peak in the FT (between 2 and $3.5 \AA$ ) with only Si-Si pairs (second neighbors) was unsucsessfull. The best result was obtained with a two shell fit ( $\mathrm{Si}-\mathrm{C}+\mathrm{Si}-\mathrm{N})$. Finally the model proposed for the as-prepared sample was made up by mixed tetrahedra SiCN3 linked together by $\mathrm{C}-\mathrm{N}$ bonds, which means that tetrahedra are not linked by their comers. With such a model, the EXAFS signal, as well as the modulus and the imaginary part of the FT was pretty well reproduced.

Our purpose is then to understand the structural evolution before the crystallisation, when the sample is treated under Ar at $1400^{\circ} \mathrm{C}$ for $24 \mathrm{H}$. The observed changes are rendered on the FT as modifications of the second and third neighbors in the intermediate range order (Figure 3). With the same approach, we are able to propose a new model presented Figure 4 . The first peak is still well reproduced by an average coordination of silicon atoms with $3 \mathrm{~N}$ and one $\mathrm{C}$ at distances equal more or less to their crystalline counterpart. The main difference, if one compares to the solution found for the as-prepared samples, comes from the fact that one has to introduce in the structure some Si-Si bonds as second neighbors. Locally, one find a structural reorganisation which appears as an early beginning of crystallisation.

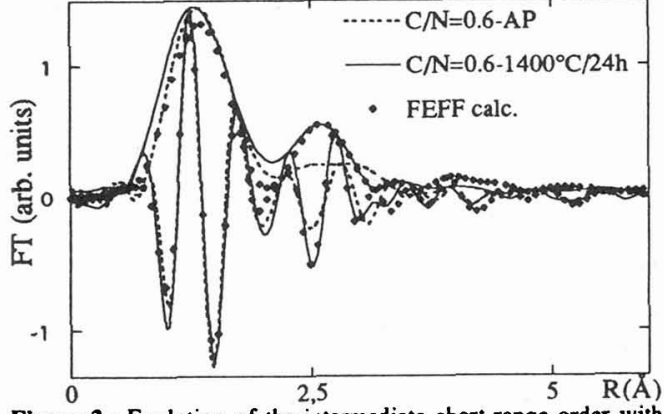

Figure 3 : Evolution of the intermediate short range order with temperature, and comparison to the result obtained through FEFF multiple scattering calculations (magnitude and imaginary part)

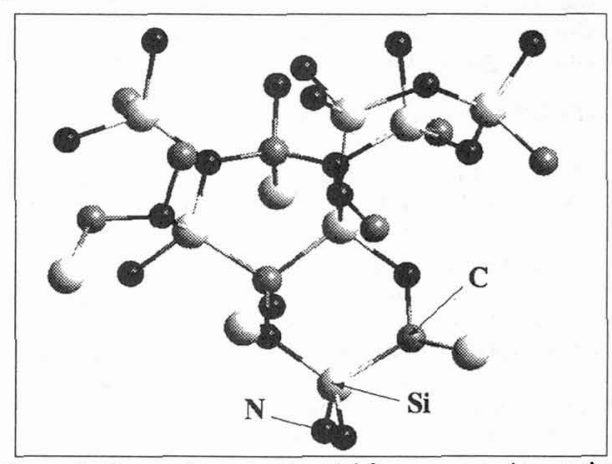

Figure 4 : Proposed structural model for a preceramic nanosized $\mathrm{Si} / \mathrm{C} / \mathrm{N}$ powder treated under Ar at $1400^{\circ} \mathrm{C}$ for $24 \mathrm{H}$.

The model tested on the central Si atoms through FEFF calculations matches pretty well to the experimental result, as evidenced figure 3 where the FT of the calculated EXAFS signal is compared to the one of the experimental one. At this temperature, the conclusion is the stability of mixed short range order around silicon atoms (SiN3C), and the decrease of intertrahedra lenght by the creation of $\mathrm{Si}-\mathrm{N}(\mathrm{C})$-Si pairs.

\section{References}

[1] Cauchetier M., Croix O., Herlin N., Luce M., J. Am. Ceram. Soc 77, (1994), 993-998.

[2] Ténégal F., Flank A.-M., Herlin N., Phys. Rev. B. in press

[3] Pettifer R.F., Glanfield A., Gardelis S., Hamilton B., Dawson P., Smith A.D., Physica B 208\&209 (1995) 484-486. 